\title{
Dinoflagellate bloom formation in natural assemblages with diatoms: nutrient competition and growth strategies in Baltic spring phytoplankton
}

\author{
Anke Kremp ${ }^{1, *}$, Timo Tamminen ${ }^{2}$, Kristian Spilling $^{2}$ \\ ${ }^{1}$ Tvärminne Zoological Station, University of Helsinki, 10900 Hanko, Finland \\ ${ }^{2}$ Finnish Environment Institute, PO Box 140, 00251 Helsinki, Finland
}

\begin{abstract}
In temperate coastal waters, the spring bloom, which commonly dominates the seasonal productivity cycle, is typically composed of cold-water diatoms. In the Baltic Sea, dinoflagellates are a regular component of the spring phytoplankton assemblage, and recent evidence suggests that their proportion might be increasing relative to diatoms. A concomitant decrease in terrestrial Si discharges and an increase in other nutrients have been considered as a possible cause of such development, as they might lead to a deteriorating competitive position of co-occurring diatoms. Using mesocosms, we studied the effects of variable nutrient additions and nutrient supply ratios on species composition and dominance patterns of natural spring phytoplankton communities from the coastal northern Baltic Sea. The experiments were repeated in 3 consecutive years to investigate to what extent variability of initial community composition and relative abundance of co-occurring species affect bloom development and species dominance. The results showed that bloom formation and dominance of the dinoflagellate Woloszynskia halophila primarily depended on the size of the inoculum's population and the relative abundance of co-occurring diatoms. Variations in dissolved inorganic silicon:(nitrate + phosphate) $[\mathrm{DSi}:(\mathrm{N}+\mathrm{P})]$ ratios did not have major effects on phytoplankton development and composition. Additions of $\mathrm{N}$ and $\mathrm{P}$, as well as increased irradiance, generally stimulated the growth of diatoms, but could not alter the outcome of competition between diatoms and dinoflagellates when the latter were initially dominant. Our results emphasize the importance of efficient recruitment strategies and initial conditions for dinoflagellate bloom formation. This implies dinoflagellate bloom sensitivity to hydrographic conditions and thus to projected climatic change, as well as different roles for diatoms and dinoflagellates along the coastal/offshore gradient.
\end{abstract}

KEY WORDS: Dinoflagellate blooms · Diatoms - Baltic Sea - DSi · Eutrophication · Recruitment Phytoplankton spring bloom $\cdot$ Woloszynskia halophila

\section{INTRODUCTION}

Large seasonal phytoplankton blooms are common in temperate and boreal coastal waters, where they typically contribute a major fraction of the annual new production, and provide pulsed sources of organic carbon as fuel for higher trophic levels in the coastal ecosystem. Being coupled to the seasonal dynamics of freshwater outflow, nutrient conditions, temperature, and water column stratification, such blooms generally follow a typical succession cycle
(Harris 1986). However, recently the natural pattern of phytoplankton succession in coastal regions has been increasingly modified by changes in phytoplankton composition, shifts in dominance patterns, and the recurrent occurrence of 'exceptional', often toxic or otherwise harmful algal blooms (Smayda 1990, Hallegraeff 2004).

In the Baltic Sea, there are indications that phytoplankton succession and community structure might be shifting from diatom to dinoflagellate dominance during the phytoplankton spring bloom season (Was- 
mund \& Uhlig 2003). Since the early 1980s, 'red tides' of cold-water dinoflagellates have frequently been observed in the central and northern parts of the Baltic (Jaanus et al. 2006), where they compete with the other species of the phytoplankton spring bloom assemblage, particularly diatoms (Niemi 1975). Several species are involved in these dinoflagellate mass occurrences (Kremp et al. 2005). At the SW coast of Finland, the blooms are caused by Woloszynskia halophila (Biecheler) Elbrächter et Kremp, which regularly forms large numbers of resistant resting cysts at the end of the growth period.

Although diatoms and dinoflagellates appear to be functional surrogates, as both are able to exhaust the wintertime pools of inorganic nutrients and produce bloom-level biomasses in the coastal northern Baltic (Heiskanen 1998), the relative abundance of the 2 algal groups, or the dominance of either, may have specific consequences for the nutrient cycling in the pelagic system. While diatoms, which typically sink out of the system intact, are readily remineralized once they are deposited at the sediment surface, dinoflagellates disintegrate in the water column and assimilated nutrients are regenerated in the productive surface layer (Heiskanen 1998). Their cysts, on the other hand, are resistant to degradation and the organic matter settling as cysts to the bottom is thus not readily available to the benthic system. Through such different effects on the pathways of nutrient cycling, a possible shift in dominance patterns may have ecosystem-wide consequences in the northern Baltic Sea. At present, both the causes and consequences of a shifting balance between diatoms and dinoflagellates are, however, poorly understood.

Dinoflagellate blooms occurring under spring conditions, which typically select for diatoms (MartinJézéquel et al. 2000), are a peculiar phenomenon. Dinoflagellates are generally considered slow growers with a low maximum uptake capacity for dissolved inorganic nutrients (Smayda 1997), which makes them inferior competitors in situations when nutrients are plentiful. To prevail in the phytoplankton community, they must either be favored by environmental settings that discriminate against competing phytoplankton, and/or possess adaptations to compensate for their competitive disadvantage.

Altered nutrient supply ratios associated with eutrophication have been considered as a major reason for the ongoing shifts in phytoplankton community structure (Hecky \& Kilham 1988, Anderson et al. 2002). They may change the patterns of nutrient limitation, which in turn should lead to selection of different species according to their optimum nutrient ratios for growth (Tilman 1982, Hecky \& Kilham 1988). The decreased DSi:N (dissolved inorganic silicon:nitrate) ratios associated with eutrophication (Conley et al. 1993, Rahm et al. 1996), and/or decreased riverine DSi loading of coastal waters due to river damming (Humborg et al. 2004), have been discussed as one possible scenario for the discrimination of diatoms in favor of non-siliceous phytoplankton (Officer \& Ryther 1980, Smayda 1990), as they may lead to a shift from $\mathrm{N}$ to DSi limitation of diatom growth (Egge \& Aksnes 1992, Sommer 1994, 1998, Gilpin et al. 2004). For the Baltic Sea, it is not yet known whether anthropogenic nutrient loading or the present trend of decreasing DSi availability (Rahm et al. 1996, Papush \& Danielsson 2006) play a role in the increasing occurrence of dinoflagellate blooms during spring.

Water column stratification is generally considered as another condition that selects for motile dinoflagellates (Margalef 1978). The physical processes leading to water column stratification are, to a large extent, driven by weather conditions, suggesting that dinoflagellate bloom phenomena could be related to changing climatic conditions (Belgrano et al. 1999, Edwards \& Richardson 2004). Long-term data analyses also indicate that the spring dinoflagellate blooms in the Baltic Sea may be related to changes in weather-related stratification patterns (Wasmund et al. 1998); however, the exact mechanisms underlying this possible relationship are not understood.

Although the habitat properties of eutrophicated and stratified waters may explain the selection of life forms typical for bloom species in theory, blooms of individual species often remain largely unpredictable (Anderson \& Garrison 1997). Particularly in multispecies communities, such as the phytoplankton spring bloom in the Baltic Sea, successful prevalence in the competition for resources may entirely depend on initial conditions (Huisman \& Weissing 2001). Besides hydrochemical and hydrographic conditions, those may include presence and relative abundance of competitors and grazers, as well as specific recruitment strategies (Anderson et al. 2002, McQuoid \& Godhe 2004). 'Being in the right place at the right time' may be a more important prerequisite for successful prevalence of a species in a community than favourable habitat conditions or ecophysiological adaptations (Smayda \& Reynolds 2001, Anderson et al. 2002).

To better understand the causes and mechanisms underlying the prevalence of dinoflagellates in the northern Baltic Sea spring bloom, and a possible relationship to the ongoing environmental changes, we investigated the role of nutrients and initial community composition on the dominance of diatoms vs. dinoflagellates in the coastal spring bloom phytoplankton community. By considering variability of the inoculum's community, we wanted to address initial selection of diatoms or dinoflagellates by respective hydro- 
graphic conditions. Using mesocosms, we studied the effects of variable nutrient additions and nutrient supply ratios on species composition and dominance patterns of natural spring phytoplankton communities. To examine the effects of initial composition and relative abundance of co-occurring species on bloom development and species dominance, the experiments were repeated with 3 different initial communities in 3 consecutive years.

\section{MATERIALS AND METHODS}

Experimental setup. Three mesocosm experiments were conducted in spring 2003, 2004 and 2005 under laboratory conditions at the Tvärminne Zoological Station, University of Helsinki. The experimental setup consisted of a control unit of non-manipulated natural sea water, and 3 nutrient manipulation treatments: (1) N and P (phosphate) added; (2) DSi added; and (3) N, P and DSi added. In 2004, 2 treatment sets were run at 2 different light conditions. A summary of the experimental design and initial conditions in the experimental units is given in Table 1.

For each experiment, 4 (in 2003 and 2005) or 8 (in 2004), containers were filled with natural surface water and pre-screened with a $200 \mu \mathrm{m}$ mesh-size net to remove metazooplankton. Water was collected during

Table 1. Day 0 concentrations of inorganic nutrients $\left(\mu \mathrm{g}^{-1}\right)$, chl a $\left(\mu \mathrm{g} \mathrm{l}^{-1}\right)$ and biomass ( $\mu \mathrm{g} \mathrm{C}^{-1}$, dinoflagellates and diatoms combined) in experimental mesocosms in 2003, 2004 and 2005. Irradiance $=17$ and $85 \mu \mathrm{mol} \mathrm{m}^{-2} \mathrm{~s}^{-1}$ in low- and high-light mesocosms, respectively

\begin{tabular}{|c|c|c|c|c|c|}
\hline Date started & Parameter & Control & $\mathrm{N}+\mathrm{P}$ & DSi & $\mathrm{N}+\mathrm{P}+\mathrm{DSi}$ \\
\hline \multicolumn{6}{|l|}{ Low-light } \\
\hline \multirow[t]{5}{*}{ April 2, 2003} & $\mathrm{NO}_{3}-\mathrm{N}$ & 40.6 & 190 & 38.6 & 201 \\
\hline & $\mathrm{PO}_{4}-\mathrm{P}$ & 5.9 & 35.5 & 5.9 & 36.2 \\
\hline & DSi & 308 & 308 & 736 & 736 \\
\hline & Chl a & 24.0 & 24.9 & 24.2 & 23.7 \\
\hline & Biomass & 281.1 & 377.1 & 291.0 & 366 \\
\hline \multirow{5}{*}{ March 24, 2004} & $\mathrm{NO}_{3}-\mathrm{N}$ & 87.4 & 274 & 87.7 & 263 \\
\hline & $\mathrm{PO}_{4}-\mathrm{P}$ & 32.9 & 63.1 & 33.2 & 62.8 \\
\hline & $\mathrm{DSi}$ & 484 & 490 & 838 & 836 \\
\hline & Chl a & 7.1 & 7.2 & 7.9 & 7.3 \\
\hline & Biomass & 128.2 & 150.0 & 151.5 & 171.9 \\
\hline \multicolumn{6}{|l|}{ High-light } \\
\hline \multirow[t]{5}{*}{ March 24, 2004} & $\mathrm{NO}_{3}-\mathrm{N}$ & 85.2 & 254 & 83.2 & 251 \\
\hline & $\mathrm{PO}_{4}-\mathrm{P}$ & 31.6 & 62.6 & 33.5 & 62.9 \\
\hline & $\mathrm{DSi}$ & 485 & 487 & 833 & 827 \\
\hline & Chl a & 6.8 & 7.5 & 7.9 & 7.4 \\
\hline & Biomass & 172.0 & 184.4 & 198.1 & 170.3 \\
\hline \multirow[t]{5}{*}{ April 7, 2005} & $\mathrm{NO}_{3}-\mathrm{N}$ & 98.3 & 258 & 105 & 253 \\
\hline & $\mathrm{PO}_{4}-\mathrm{P}$ & 15.2 & 42.8 & 15.9 & 45.6 \\
\hline & $\mathrm{DSi}$ & 551 & 560 & 859 & 871 \\
\hline & Chl a & 3.0 & 2.9 & 3.1 & 3.1 \\
\hline & Biomass & 10.3 & 10.9 & 10.2 & 9.3 \\
\hline
\end{tabular}

ice break-up by standing on the ice edge near the Storfjärden monitoring station at the SW coast of Finland $\left(59^{\circ} 51^{\prime} \mathrm{N}, 23^{\circ} 13^{\prime} \mathrm{E}\right)$. In 2003 and 2004, white plastic (PE) $80 \mathrm{~L}$ barrels were used as experimental units, whereas in 2005, 25 L transparent polycarbonate carboys were used.

Ice break-up typically coincides with the initiation of the annual spring bloom in the area (Niemi 1975), and the captured phytoplankton community was assumed to represent the seed community for the spring phytoplankton bloom. The timing of ice break-up varies between years, and accordingly the experiments were started on different dates in subsequent years, depending on the ice situation: 2 April 2003, 24 March 2004, and 7 April 2005 (Fig. 1).

After filling each mesocosm on the ice, they were immediately brought to the laboratory and placed into a walk-in incubator set to $+2^{\circ} \mathrm{C}$. The mesocosms were illuminated by daylight spectrum fluorescent tubes (Philips TLD-95) on a 12:12 light:dark cycle corresponding to the ambient light cycle. Irradiance was adjusted to $17 \mu \mathrm{mol} \mathrm{m}{ }^{-2} \mathrm{~s}^{-1}$ for the low-light treatment (L), which was applied in the 2003 experiment and in 1 treatment series in 2004, and to $85 \mu \mathrm{mol} \mathrm{m} \mathrm{m} \mathrm{s}^{-1}$ for the high-light treatment $(\mathrm{H})$ in 2004, and to the 4 experimental units in 2005. Filtered $(0.2 \mu \mathrm{m})$ air was bubbled into the mesocosms to keep a low level of turbulence and to ensure $\mathrm{CO}_{2}$ saturation.

Natural nutrient conditions were manipulated by additions of $\mathrm{NO}_{3}-\mathrm{N}$

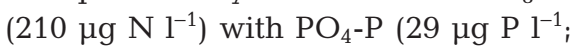
$\mathrm{N}+\mathrm{P}$ treatment), and/or $\mathrm{SiO}_{2}-\mathrm{Si}(421 \mu \mathrm{g}$ Si $l^{-1}$; DSi treatment) in a factorial $2^{2}$ experimental design, expanded into a $2^{3}$ design in 2004 with the addition of 2 light levels. Nutrient additions (see Table 1 for Day 0 nutrient concentrations, after additions into experimental units) were targeted at approximately doubling the typical wintertime concentrations in the area, while maintaining balanced Redfield/Brzezinski ratios between the added nutrients (Brzezinski 1985). As the successive years represented different initial conditions due to differences in ice break-up and other meteorological conditions, the ambient nutrient concentrations of each experiment represented varying phases of the early bloom period, between wintertime levels and spring depletion period (Fig 1).

Sampling and analyses. Mesocosms were sampled for chlorophyll a ( $\mathrm{chl} a)$, nutrient and phytoplankton analyses 

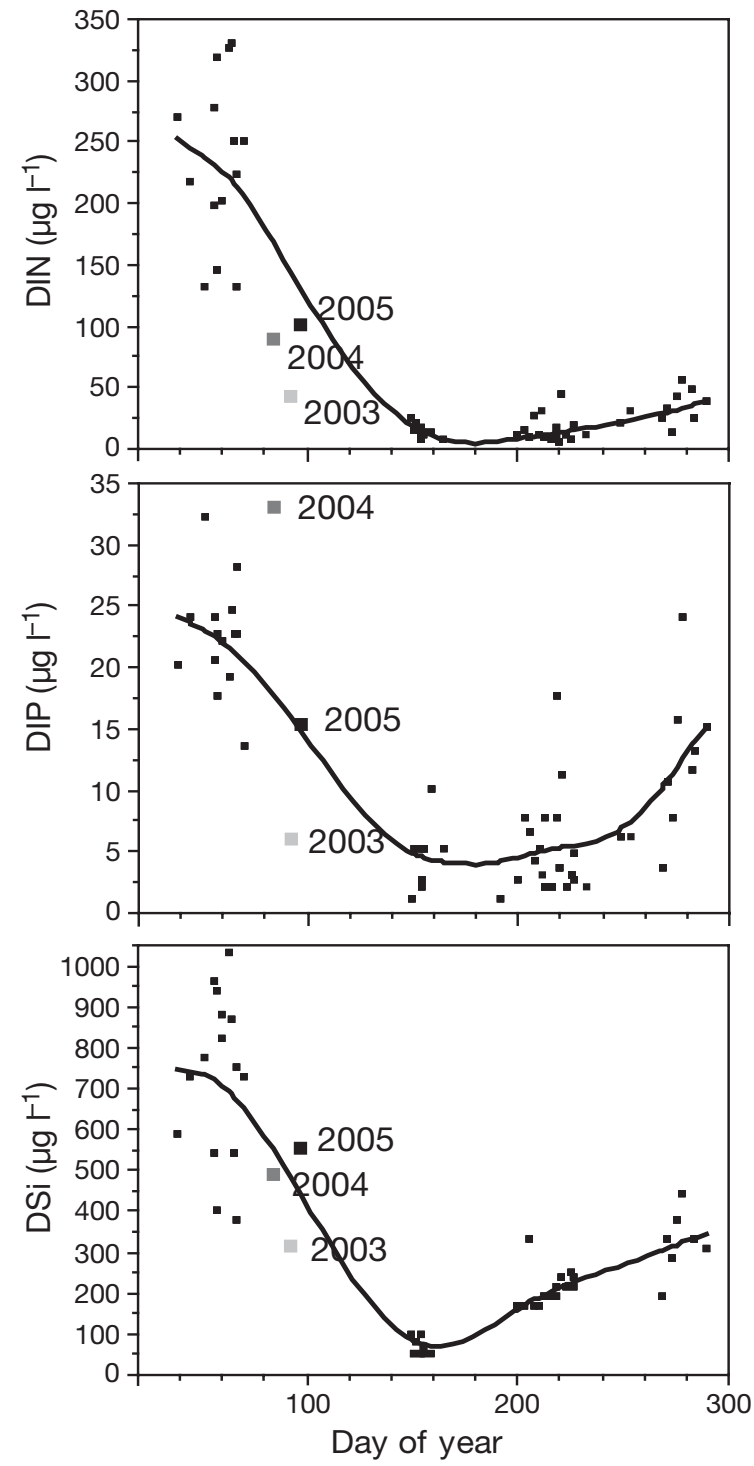

Fig. 1. Long-term monitoring data on inorganic nutrients (DIP = phosphate, DIN = nitrate + ammonium, and DSi $=$ sili-

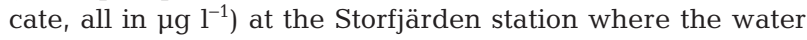
for the experimental mesocosms was sampled. Data from 1975 to 2006 are plotted on joint annual axes and the lines drawn with spline smoother. The initial conditions for the 3 experiments are depicted with their respective year (2003, 2004 and 2005)

immediately after the addition of nutrients on Day 0 , and subsequently every 2 to $3 \mathrm{~d}$ over a period of approximately $5 \mathrm{wk}$. Prior to sampling, which took place at the beginning of the daily light period, the contents of the mesocosms were stirred with a polycarbonate rod to ensure an even distribution of phytoplankton.

Samples for nutrient and chl a measurements were processed immediately. Nutrient concentrations $\left(\mathrm{NO}_{3}-\mathrm{N}\right.$, $\mathrm{PO}_{4}-\mathrm{P}$ and $\mathrm{DSi}$ ) were determined manually in duplicate according to the methods of Grasshoff et al. (1983). For chl $a$ analyses, $50 \mathrm{ml}$ duplicate samples were filtered onto glass fiber filters (Whatman GF/F) and extracted in $10 \mathrm{ml}$ of $94 \%$ ethanol for $24 \mathrm{~h}$ in the dark at room temperature. Chl a was measured on a Shimadzu RFPC-5001 fluorometer calibrated with pure chl a (Sigma).

Phytoplankton samples were preserved with acid Lugol's solution. Prior to microscopic analysis, volumes of 50 and $25 \mathrm{ml}$ were set up for concentration in Utermöhl chambers and allowed to settle for at least $24 \mathrm{~h}$. Diatoms and dinoflagellates, identified to species or genus, were counted with an inverted light microscope (Leica DM IRB Wetzlar). Cells were grouped into 2 size categories $(>10 \mu \mathrm{m}$ and $<10 \mu \mathrm{m})$ which were counted separately at $200 \times$ and $787 \times$ magnification. At least half of the chamber bottom was screened when cell densities were low; otherwise 400 cells were counted, if possible, for each category. Cell dimensions of diatoms and dinoflagellates were measured on 25 randomly selected cells of each species, and biovolumes were calculated using formulas given for standard geometric shapes of phytoplankton taxa (Sun \& Liu 2003). Biovolume values were converted to carbon according to the recommendations of Menden-Deuer \& Lessard (2000). Growth rates of the dominant species $\left(\mu_{n}\right)$ were calculated in each treatment as net rates of increase over the period from initiation to chl a peak using the growth rate equation:

$$
\mu=\left(\ln N-\ln N_{0}\right) / t
$$

where $N_{0}$ and $N$ are the cell numbers per unit volume at the beginning and the end of the time interval $(t)$, respectively (Fogg \& Thake 1987).

Statistical analyses. In order to statistically evaluate the effects of different treatments used in the nonreplicated factorial experimental set-up, we constructed linear regression models using the ' $\mathrm{lm}$ ' function in R software (version 2.3.1, 'stats' package). The dependent variable was percentage of dinoflagellate biomass of total (dinoflagellate + diatom) biomass at the time of chl a peak, and different treatments and their combinations were used as independent variables. Although basic treatments (nutrient additions) were identical each year, there were modifications to the design in different years in terms of light levels and number of units. We thus pooled comparable treatments ( $\mathrm{N}+\mathrm{P}$ enrichment, $\mathrm{DSi}$ enrichment) pairwise over successive years into joint analysis, including the experiment year as a treatment (Year), representing the effect of initial conditions. This scheme resulted in separate analyses of low light (2003, one treatment set of 2004) and high light (other set of 2004, 2005) units.

The treatment effect contrasts and all interaction contrasts were plotted against their normal order scores (see Fig. 3). Insignificant treatment effects form a straight line on the normal probability plot, while 
contrasts that deviate from this line represent significant treatment effects (Box \& Draper 1978, Berthouex \& Brown 1994).

The experimental design used during 2004 was a complete $2^{3}$ factorial design, and the effects of treatments and their combinations were analyzed by repeated measures ANOVA (see Table 5). For this analysis, we used the samplings taken from the start until Day 15, when the biomass peaks were recorded, altogether 7 sampling points. Dependent variables in analyses were the percentage dinoflagellate biomass of total (dinoflagellate + diatom) biomass, and separately Woloszynskia halophila and total diatom biomasses.

\section{RESULTS}

\section{Initial nutrient conditions and phytoplankton composition in 3 consecutive years}

Initial concentrations of $\mathrm{NO}_{3}-\mathrm{N}, \mathrm{PO}_{4}-\mathrm{P}$ and $\mathrm{DSi}$ in our experiments (Table 1) corresponded to the long-term nutrient range typical for the early spring period in the study area, but differed from each other in terms of timing along the springtime nutrient depletion. In Fig. 1, a compilation of monitoring data from the sampling station for 3 decades is presented over a joint annual axis. These data are based on infrequent sampling annually (in general, only 4 sampling occasions per year), and therefore it is not possible to estimate average bloom depletion rates or residual concentrations reliably. More intensive sampling in specific years at nearby stations indicate that the depletion of wintertime accumulation of inorganic nutrients takes place within a 2 to $3 \mathrm{wk}$ time window, with considerable interannual variability in timing (Niemi 1973, Heiskanen \& Kononen 1994, Tamminen 1995).

In 2003, initial nutrient concentrations were generally lower than in 2004 and 2005, indicating a more advanced bloom initiation stage compared to the latter years (Fig. 1). Particularly high initial concentrations of inorganic phosphorus were measured in 2004, in agreement with large-scale interannual variability in nutrient conditions of the Gulf of Finland (Finnish Environment Institute, data not shown).

The interannual differences in ambient nutrient availability at the time of ice break-up were reflected in differences in initial chl a and phytoplankton biomass concentrations (Table 1), with relatively high values in 2003 and low values, differing by an order of magnitude, in 2005. In 2004, chl $a$ and phytoplankton biomass levels were intermediate, at values representing approximately half of the concentrations in 2003. The initial $\mathrm{chl} a$ and biomass values in the 4 (2003 and 2005) or 8 (2004) experimental units were highly similar within each experiment (CVs between units in 2003, 2004 and 2005, respectively: $2.2,5.0$ and $2.4 \%$ for chl $a_{i}$ 15.1, 13.2 and $6.3 \%$ for biomass), confirming that the initial situation in the experimental units was comparable.

The initial phytoplankton community generally consisted of cold-water dinoflagellates and diatoms. The most abundant and recurrent species were the dinoflagellates Woloszynskia halophila, Peridiniella catenata and Scrippsiella hangoei, as well as the diatoms Chaetoceros spp., Pauliella taeniata, Thalassiosira levanderi, T. baltica and Skeletonema costatum, which all are typical members of the spring phytoplankton community in the northern Baltic Sea. Despite the relatively consistent species composition, the absolute abundances and relative contributions of the different taxa to the phytoplankton community varied considerably between years (Table 2, Fig. 2).

In 2003, the initial community was dominated by the diatoms Chaetoceros spp. and Pauliella taeniata, which at the time of ice break-up had established populations of $>2 \times 10^{6}$ cells $\mathrm{l}^{-1}$. The dinoflagellate Woloszynskia halophila, though relatively abundant, contributed only a minor fraction $(<10 \%)$ to the total phytoplankton biomass. In contrast, the initial community in 2004 was entirely dominated by $W$. halophila, and diatoms and other dinoflagellates were only minor components of the phytoplankton community, which generally occurred at low abundances.

Initial phytoplankton abundances were very low in spring of 2005. However, the community was more

Table 2. Initial abundances of common dinoflagellate and diatom taxa in the 2003, 2004 and 2005 experiments. Mean values ( \pm SD) of initial counts are presented for the $4(2003,2005)$ or 8 (2004) experimental units. Species with contributions of $>1 \%$ of total dinoflagellate + diatom abundance are presented

\begin{tabular}{|lccc|}
\hline \multirow{2}{*}{ Taxon } & \multicolumn{3}{c|}{ Cell concentration $\left(\mathrm{cells} \times 10^{3} \mathrm{l}^{-1}\right)$} \\
\cline { 2 - 4 } & \multicolumn{2}{c}{2003} & 2004 \\
\hline Dinoflagellates & & & \\
Woloszynskia halophila & $46.72( \pm 8.45)$ & $252.20( \pm 33.34)$ & $3.48( \pm 0.61)$ \\
Peridiniella catenata & & & $2.46( \pm 0.70)$ \\
Scrippsiella hangoei & & & $2.08( \pm 0.64)$ \\
Diatoms & & & \\
Chaetoceros spp. & $2183.62( \pm 166.38)$ & $24.96( \pm 4.19)$ & $30.52( \pm 15.37)$ \\
Pauliella taeniata & $2129.38( \pm 533.87)$ & $44.03( \pm 15.53)$ & $10.53( \pm 2.00)$ \\
Thalassiosira levanderi & $107.27( \pm 22.50)$ & $14.67( \pm 4.46)$ & $7.32( \pm 1.96)$ \\
Thalassiosira baltica & & $3.83( \pm 1.50)$ & $5.58( \pm 1.04)$ \\
Skeletonema costatum & & $17.62( \pm 7.81)$ & $7.36( \pm 1.11)$ \\
small centric diatom & & & $42.01( \pm 11.46)$ \\
& & & \\
\hline
\end{tabular}




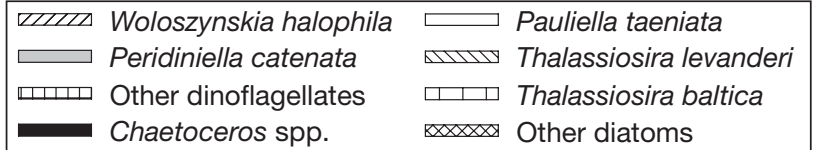
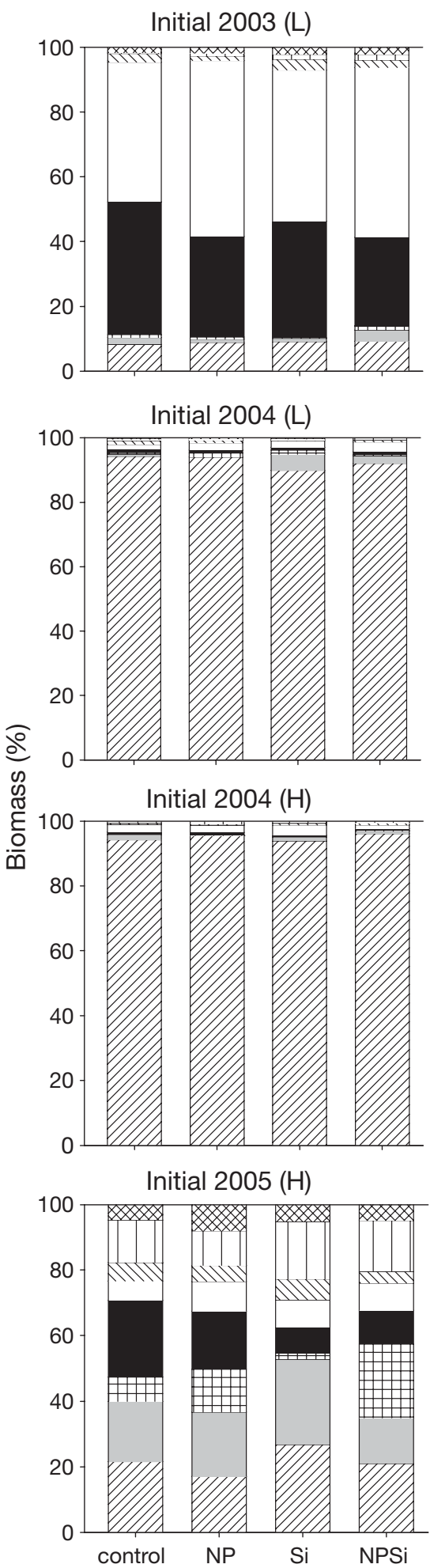

Chl a peak $2003(\mathrm{~L})$

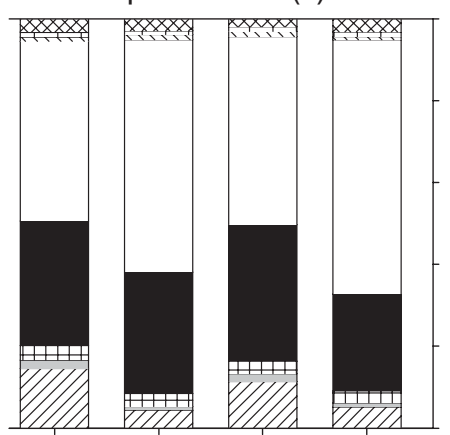

Chl a peak 2004 (L)

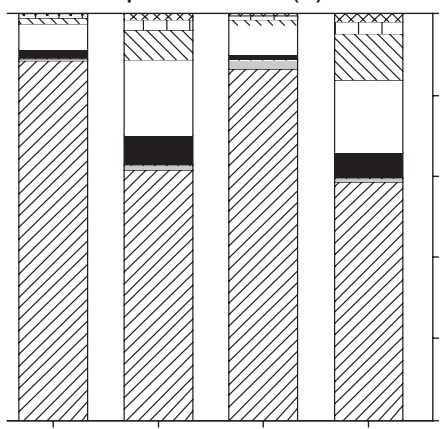

Chl a peak $2004(\mathrm{H})$

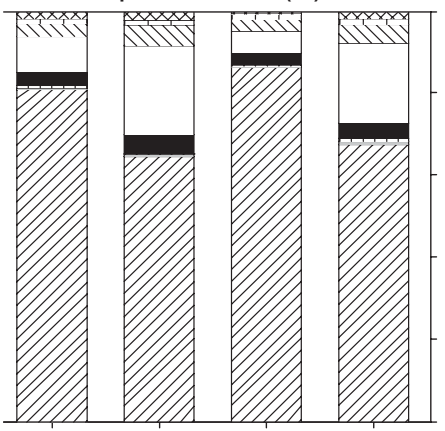

Chl a peak $2005(\mathrm{H})$

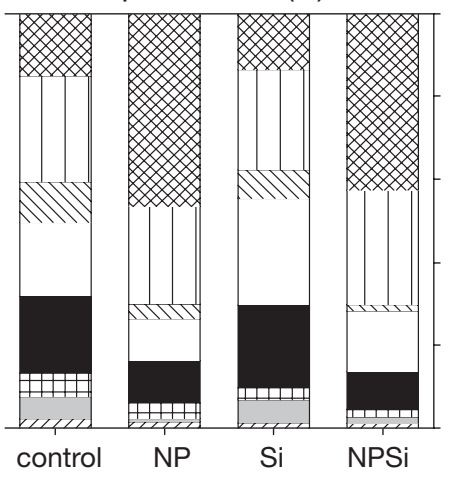

diverse than in the previous years. Woloszynskia halophila co-occurred with 2 other coldwater dinoflagellate species, Peridiniella catenata and Scrippsiella hangoei, and together the 3 dinoflagellate species constituted approximately half of the initial phytoplankton biomass (Fig. 2). In addition to the diatom taxa encountered in the previous years, an unidentified small centric diatom was abundant in the initial community in 2005. Phytoplankton abundances were generally consistent among the experimental units at the start of each experiment, with most standard deviations for individual taxa representing CVs of less than $35 \%$ (Table 2 ).

\section{Environmental parameters at chl a peak}

The concentrations of nutrients, chl $a$ and phytoplankton biomass at the time of the chl a peak in the experimental units are presented for each year in Table 3 . The chl a peak consistently followed the depletion of $\mathrm{NO}_{3}-\mathrm{N}$ and $\mathrm{PO}_{4}$-P. In treatments without $\mathrm{N}$ and $\mathrm{P}$ additions, the chl a peak occurred earlier and maximum chl a concentrations were much lower than in treatments with the respective nutrients added. The chl a peaks occurred earlier at the higher irradiance level compared to the low-light treatment in 2004.

In 2003, when ambient nitrate and phosphate concentrations had already been depleted to approximately half of the usual winter concentrations at the initiation of the experiment, chl a and biomass maxima were reached within a few days in the mesocosms without $\mathrm{N}+\mathrm{P}$ additions, and the values were comparable irrespective of different DSi: $(\mathrm{N}+\mathrm{P})$ ratios. In the $\mathrm{N}+\mathrm{P}$ mesocosms with or without DSi addition, chl $a$ and biomass increased approximately 5- to 6-fold before nutrients were depleted (Table 3), about a week later than in the treatments without added $\mathrm{N}+\mathrm{P}$.

Fig. 2. Biomass composition in experimental mesocosms at time of initiation (left column) and chl a peak (right column) in 2003, 2004 and 2005. In 2004 two light levels were used: the low-light treatment (L) corresponded to the light conditions in 2003 $\left(17 \mu \mathrm{mol} \mathrm{m} \mathrm{m}^{-2} \mathrm{~s}^{-1}\right)$, the high-light treatment $(\mathrm{H})$ was equivalent to the light level applied in 2005 (85 $\mu \mathrm{mol}$ $\mathrm{m}^{-2} \mathrm{~s}^{-1}$ ). Major taxa with $>5 \%$ contribution to total diatom + dinoflagellate biomass and presence in all treatments are shown 
Table 3. Concentrations of inorganic nutrients $\left(\mu \mathrm{g} \mathrm{l}^{-1}\right)$, chl a $\left(\mu \mathrm{g} \mathrm{l}^{-1}\right)$ and biomass ( $\mu \mathrm{g} \mathrm{C}^{-1}$, dinoflagellates and diatoms combined) in experimental mesocosms at the time of chl a peak in 3 consecutive years. Irradiance $=17$ and $85 \mu \mathrm{mol} \mathrm{m}^{-2} \mathrm{~s}^{-1}$ in low- and high-light mesocosms, respectively

\begin{tabular}{|c|c|c|c|c|c|}
\hline Date started & Parameter & Control & $\mathrm{N}+\mathrm{P}$ & $\mathrm{DSi}$ & $\mathrm{N}+\mathrm{P}+\mathrm{DSi}$ \\
\hline \multicolumn{6}{|l|}{ Low-light } \\
\hline \multirow[t]{6}{*}{ April 2, 2003} & Chl a peak & 9 April & 14 April & 9 April & 17 April \\
\hline & $\mathrm{NO}_{3}-\mathrm{N}$ & 1.3 & 1.6 & 1.0 & 0.0 \\
\hline & $\mathrm{PO}_{4}-\mathrm{P}$ & 4.4 & 11.3 & 5.2 & 2.5 \\
\hline & DSi & 115 & 16 & 308 & 19 \\
\hline & Chl a & 31.2 & 88.5 & 31.5 & 105 \\
\hline & Biomass & 539.3 & 1394.9 & 492.6 & 1906.5 \\
\hline \multirow[t]{6}{*}{ March 24, 2004} & Chl a peak & 5 April & 20 April & 8 April & 20 April \\
\hline & $\mathrm{NO}_{3}-\mathrm{N}$ & 0.6 & 2.5 & 1.9 & 2.8 \\
\hline & $\mathrm{PO}_{4}-\mathrm{P}$ & 13.2 & 4.1 & 12.7 & 3.1 \\
\hline & $\mathrm{DSi}$ & 428 & 58 & 768 & 393 \\
\hline & Chl $a$ & 28.2 & 74.1 & 30.3 & 78.3 \\
\hline & Biomass & 798.3 & 1061.1 & 650.1 & 874.8 \\
\hline \multicolumn{6}{|l|}{ High-light } \\
\hline \multirow[t]{6}{*}{ March 24, 2004} & Chl a peak & 31 March & 8 April & 31 March & 8 April \\
\hline & $\mathrm{NO}_{3}-\mathrm{N}$ & 0.9 & 1.3 & 0.6 & 1.3 \\
\hline & $\mathrm{PO}_{4}-\mathrm{P}$ & 8.2 & 1.9 & 8.2 & 1.1 \\
\hline & $\mathrm{DSi}$ & 404 & 37 & 770 & 327 \\
\hline & Chl a & 21.7 & 57.6 & 23.4 & 56.2 \\
\hline & Biomass & 603.9 & 1378.1 & 603.5 & 1626.6 \\
\hline \multicolumn{6}{|l|}{ April 7, 2005} \\
\hline & Chl a peak & 15 April & 20 April & 15 April & 20 April \\
\hline & $\mathrm{NO}_{3}-\mathrm{N}$ & 17.6 & 5.3 & 17.6 & 5.4 \\
\hline & $\mathrm{PO}_{4}-\mathrm{P}$ & 6.5 & 3.6 & 7.9 & 3.6 \\
\hline & $\mathrm{DSi}$ & 438 & 20 & 752 & 186 \\
\hline & Chl a & 22.1 & 153 & 19.8 & 149 \\
\hline & Biomass & 135.2 & 348.1 & 145.3 & 465.2 \\
\hline
\end{tabular}

In 2004, when ambient nutrients were higher at the beginning of the experiment and the dinoflagellate Woloszynskia halophila dominated the community, the chl a peaks generally evolved more slowly than in 2003. Peak chl a values in the treatments without $\mathrm{N}+\mathrm{P}$ addition were in the same range as in 2003, whereas the corresponding biomasses were somewhat higher than in the previous year (Table 3). DSi levels remained virtually unchanged in all treatments without $\mathrm{N}+\mathrm{P}$ additions. With $\mathrm{N}+\mathrm{P}$ additions, both the timing and magnitude of chl a peaks differed according to light conditions. In the low-light $\mathrm{N}+\mathrm{P}$ enriched mesocosms, it took nearly $4 \mathrm{wk}$ before the inorganic nutrient pools were exhausted and the chl a peak was reached, but the peaks were higher than in the high-light treatments (Table 3).

In 2005, exceptionally high chl a peaks of ca. $150 \mu \mathrm{g} \mathrm{l}^{-1}$ were measured in the $\mathrm{N}+\mathrm{P}$ mesocosms (Table 3). The corresponding phytoplankton biomass, however, remained far below the values measured in the previous years in the respective treatments. In the mesocosms without $\mathrm{N}+\mathrm{P}$ additions, peak chl a concentrations, as well as phytoplankton biomasses, were lower than in the previous years. $\mathrm{N}$ and $\mathrm{P}$ were not entirely depleted in these treatments at the time of the chl a peak, and DSi was only slightly reduced. The situation was different in the $\mathrm{N}+\mathrm{P}$ enriched treatments, where the proliferating diatom community had consumed $\mathrm{N}$ and $\mathrm{P}$ and most of the initially available DSi within 2 wk.

\section{Phytoplankton development in 2003, 2004 and 2005}

The relative contribution of major taxa to the total phytoplankton biomass in the mesocosms is shown in Fig. 2. At the time of the chl a peak, diatoms were generally more abundant in the $\mathrm{N}+\mathrm{P}$ enriched mesocosms as compared to the treatments with no added $\mathrm{N}+\mathrm{P}$. Usually taxa that were initially dominant also prevailed at the time of the chlorophyll peak, irrespective of differences in nutrient or light treatments.

In 2003, the initial dominance of Chaetoceros spp. and Pauliella taeniata was maintained throughout the experiment (Fig. 2). Net growth rates of diatoms (Table 4) were generally higher in the N+P mesocosms as compared to the control and DSi treatments, resulting in higher relative biomasses at the expense of Woloszynskia halophila, which lost in proportion due to lower net growth rates. Particularly, the fraction of $P$. taeniata increased in the N+P treatments, and this effect was most pronounced at high initial DSi levels. The relative biomass of $W$. halophila increased in the treatments without added N+P. Here, diatoms generally had lower net rates of increase in contrast to W. halophila, which appeared to be stimulated in those mesocosms (Table 4).

In 2004, when the initial community was entirely dominated by Woloszynskia halophila, diatoms remained a minor compartment of the phytoplankton biomass in all treatments despite their generally high net growth rates (Table 4, Fig. 2). Even at $\mathrm{N}$ and $\mathrm{P}$ enriched conditions, which resulted in a significant increase in their relative biomass, diatoms were not able to outgrow the dinoflagellates before nutrients were depleted. Light enhanced the growth of both diatoms and dinoflagellates (Table 5), as reflected by the considerably higher net growth rates in the highlight units (Table 4). Although light had a more pronounced effect on the growth of the diatoms compared 
Table 4. Net rates of increase expressed as relative growth rates $\left(\mu_{n}\right)$ of dominant taxa $(>1 \%$ of total abundance), estimated for the period from initiation to chl a peak. (L): low light; $(\mathrm{H})$ : high light (see Table 1 for details)

\begin{tabular}{|c|c|c|c|c|c|c|c|c|}
\hline \multirow{2}{*}{ Year } & \multirow{2}{*}{ Treatment } & \multicolumn{7}{|c|}{ - Net growth rate $\mu_{n}\left(d^{-1}\right)$} \\
\hline & & $\begin{array}{c}\text { Woloszynskia } \\
\text { halophila }\end{array}$ & $\begin{array}{c}\text { Chaetoceros } \\
\text { spp. }\end{array}$ & $\begin{array}{c}\text { Pauliella } \\
\text { taeniata }\end{array}$ & $\begin{array}{c}\text { Thalassiosira } \\
\text { levanderi }\end{array}$ & $\begin{array}{c}\text { Thalassiosira } \\
\text { baltica }\end{array}$ & $\begin{array}{l}\text { Skeletonema } \\
\text { costatum }\end{array}$ & $\begin{array}{c}\text { Small centric } \\
\text { diatom }\end{array}$ \\
\hline \multirow{4}{*}{2003} & Control (L) & 0.13 & 0.05 & 0.16 & -0.01 & 0.06 & 0.16 & \\
\hline & $\mathrm{N}+\mathrm{P}(\mathrm{L})$ & 0.05 & 0.10 & 0.11 & 0.10 & 0.10 & 0.17 & \\
\hline & DSi (L) & 0.13 & 0.09 & 0.06 & 0.03 & 0.04 & 0.03 & \\
\hline & $\mathrm{N}+\mathrm{P}+\mathrm{DSi}(\mathrm{L})$ & 0.09 & 0.12 & 0.15 & 0.09 & 0.10 & 0.17 & \\
\hline \multirow[t]{8}{*}{2004} & Control (L) & 0.16 & 0.13 & 0.22 & 0.24 & 0.31 & 0.30 & \\
\hline & $\mathrm{N}+\mathrm{P}(\mathrm{L})$ & 0.08 & 0.20 & 0.15 & 0.19 & 0.17 & 0.20 & \\
\hline & DSi (L) & 0.12 & 0.13 & 0.18 & 0.21 & 0.12 & 0.25 & \\
\hline & $\mathrm{N}+\mathrm{P}+\mathrm{DSi}(\mathrm{L})$ & 0.06 & 0.17 & 0.16 & 0.20 & 0.11 & 0.25 & \\
\hline & Control (H) & 0.17 & 0.57 & 0.29 & 0.48 & 0.21 & 0.36 & \\
\hline & $\mathrm{N}+\mathrm{P}(\mathrm{H})$ & 0.14 & 0.51 & 0.37 & 0.41 & 0.32 & 0.43 & \\
\hline & DSi $(\mathrm{H})$ & 0.16 & 0.33 & 0.11 & 0.42 & 0.26 & 0.27 & \\
\hline & $\mathrm{N}+\mathrm{P}+\mathrm{DSi}(\mathrm{H})$ & 0.15 & 0.50 & 0.34 & 0.26 & 0.34 & 0.46 & \\
\hline \multirow[t]{4}{*}{2005} & Control (H) & 0.04 & 0.29 & 0.45 & 0.38 & 0.41 & 0.37 & 0.47 \\
\hline & $\mathrm{N}+\mathrm{P}(\mathrm{H})$ & 0.09 & 0.22 & 0.28 & 0.24 & 0.33 & 0.20 & 0.41 \\
\hline & $\mathrm{DSi}(\mathrm{H})$ & -0.04 & 0.44 & 0.47 & 0.33 & 0.37 & 0.24 & 0.47 \\
\hline & $\mathrm{N}+\mathrm{P}+\mathrm{DSi}(\mathrm{H})$ & 0.08 & 0.29 & 0.34 & 0.23 & 0.34 & 0.20 & 0.47 \\
\hline
\end{tabular}

to $W$. halophila, this species remained dominant in all mesocosms at both light treatments.

In 2005, the dinoflagellates, which initially constituted approximately $50 \%$ of the phytoplankton biomass, were quickly outcompeted by fastgrowing small diatoms. At the time of the chlorophyll peak, an unidentified small centric diatom species dominated the N+P mesocosms (Fig. 2). With its high growth rates, this species apparently suppressed the proliferation of the other diatoms to some extent, as reflected by their generally lower net rates of increase in those treatments (Table 4). In the treatments without $\mathrm{N}$ and $\mathrm{P}$ additions, the small centric diatom was replaced by Chaetoceros spp., Pauliella taeniata, Thalassiosira levanderi and T. baltica, which contributed with higher proportions to the biomass here as compared to the $\mathrm{N}+\mathrm{P}$ treatments.

Statistical analyses confirmed that the single most significant effect on the dominance of either group at the bloom peak was the initial situation, represented in the analysis by experiment year (Fig. 3). DSi treatment had no effect on the dominance pattern, and although the combined $\mathrm{N}+\mathrm{P}$ addition appeared to enhance diatom
Table 5. Repeated measures ANOVA of the 2004 experiment. NP = nitrogen and phosphorus enrichment, DSi = dissolved silicate enrichment, Light = high-light treatment. The analysis was carried out for the repeated measures from the start until the major peak of biomass (Days 0 to 15, 7 sampling points). (A) Percentage dinoflagellate biomass of total (dinoflagellate + diatom) biomass; (B) Woloszynskia halophila biomass; and (C) total diatom biomass. Significance level $\left({ }^{* *} \mathrm{p} 0.01,{ }^{* * *} \mathrm{p} 0.001\right)$ and direction (positive/negative) of the treatment effect are indicated

\begin{tabular}{|c|c|c|c|c|c|c|}
\hline Treatment & $\mathrm{df}$ & SS & MS & $F$ & $\mathrm{p}$ & \\
\hline \multicolumn{7}{|c|}{ (A) Percentage of dinoflagellates } \\
\hline NP & 1 & 1048.26 & 1048.26 & 29.644 & 0.000 & ${ }^{* * *}(-)$ \\
\hline $\mathrm{DSi}$ & 1 & 19.56 & 19.56 & 0.553 & 0.461 & \\
\hline Light & 1 & 361.56 & 361.56 & 10.225 & 0.002 & ${ }^{* *}(-)$ \\
\hline NP:DSi & 1 & 0.75 & 0.75 & 0.021 & 0.885 & \\
\hline NP:Light & 1 & 141.30 & 141.30 & 3.996 & 0.051 & \\
\hline DSi:Light & 1 & 46.23 & 46.23 & 1.307 & 0.259 & \\
\hline NP:DSi:Light & 1 & 0.00 & 0.00 & 0.000 & 0.997 & \\
\hline Residuals & 47 & 1661.98 & 35.36 & & & \\
\hline \multicolumn{7}{|c|}{ (B) Woloszynskia halophila biomass ( $\mu \mathrm{g} \mathrm{C}^{-1}$ ) } \\
\hline NP & 1 & 56073 & 56073 & 3.010 & 0.089 & $(-)$ \\
\hline $\mathrm{DSi}$ & 1 & 5293 & 5293 & 0.284 & 0.597 & \\
\hline Light & 1 & 476120 & 476120 & 25.561 & 0.000 & ${ }^{* * *}(+)$ \\
\hline $\mathrm{NP}: \mathrm{DSi}$ & 1 & 17406 & 17406 & 0.935 & 0.339 & \\
\hline NP:Light & 1 & 39052 & 39052 & 2.097 & 0.154 & \\
\hline DSi:Light & 1 & 55553 & 55553 & 2.982 & 0.091 & \\
\hline NP:DSi:Light & 1 & 52500 & 52500 & 2.819 & 0.100 & \\
\hline Residuals & 47 & 875460 & 18627 & & & \\
\hline \multicolumn{7}{|c|}{ (C) Total diatom biomass $\left(\mu \mathrm{g} \mathrm{C} \mathrm{l}^{-1}\right)$} \\
\hline NP & 1 & 96700 & 96700 & 13.298 & 0.001 & $* * *(+)$ \\
\hline $\mathrm{DSi}$ & 1 & 6245 & 6245 & 0.859 & 0.359 & \\
\hline Light & 1 & 117090 & 117090 & 16.102 & 0.000 & ${ }^{* * *}(+)$ \\
\hline NP:DSi & 1 & 1072 & 1072 & 0.148 & 0.703 & \\
\hline NP:Light & 1 & 68990 & 68990 & 9.487 & 0.003 & ${ }^{* *}(+)$ \\
\hline DSi:Light & 1 & 1465 & 1465 & 0.202 & 0.656 & \\
\hline NP:DSi:Light & 1 & 1939 & 1939 & 0.267 & 0.608 & \\
\hline Residuals & 47 & 341780 & 7272 & & & \\
\hline
\end{tabular}


growth more than dinoflagellates, this effect was hardly significant and overshadowed by differences between the years.

Interestingly, Woloszynskia halophila growth rates seemed to be negatively affected by $\mathrm{N}+\mathrm{P}$ additions in low light (Table 4), both in situations where it represented a minor (year 2003) or a major (year 2004) component of the community (Fig. 2). At high light, no corresponding negative nutrient effect could be seen, or nutrient additions slightly increased $W$. halophila growth rates (Table 4).

\section{Dinoflagellate bloom dynamics in 2004}

The development of inorganic nutrients, chl $a$, phytoplankton biomass composition and abundances of dominant species are shown in Figs. 4 to 6 for the initially dinoflagellate-dominated 2004 experiment. The increase in chl $a$, reflecting the build-up of phytoplankton biomass, followed the depletion of phosphate and nitrate in the mesocosms (Fig. 4). In the low-light mesocosms, chlorophyll concentrations increased more slowly but reached higher maxima in the end, compared to the high-light mesocosms.

The biomass of all 8 mesocosms was dominated by the dinoflagellate Woloszynskia halophila throughout the experiment (Fig. 5). Generally this species

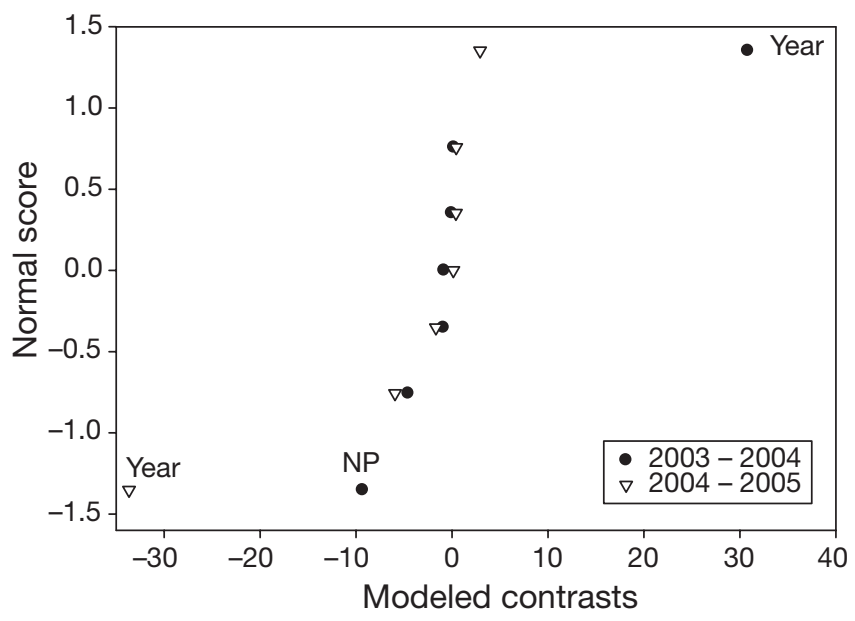

Fig. 3. Estimation of significant treatment effects on percentage of dinoflagellates of the total (dinoflagellate + diatom) biomass at the chl a peak, by normal probability plot for the years 2003-2004 (•, low light) and 2004-2005 ( $\nabla$, high light). Treatments used were the NP and DSi additions, and the experiment year. Light was excluded in the analysis by comparing the same light treatment between the years. Insignificant treatment effects form a straight line; deviations from this line represent major manipulation effects (Box \& Draper 1978, Berthouex \& Brown 1994). In both analyses, the initial conditions (represented by 'Year') stood out as the most significant cause for community composition reached significantly higher biomasses in the highlight (800 to $1500 \mathrm{\mu g} \mathrm{C} \mathrm{l}^{-1}$ ) compared to the low-light mesocosms (600 to $700 \mu \mathrm{g} \mathrm{C} \mathrm{l}^{-1}$ ) (Table 5). Nutrient additions did not stimulate the development or magnitude of $W$. halophila biomass. In fact, at the lower irradiance level, the highest biomass values were detected in the control treatment, and the negative $\mathrm{N}+\mathrm{P}$ effect on $W$. halophila was consequently almost significant (Table 5).

Diatoms gained considerable proportions of biomass in the N+P mesocosms at both low and high irradiance, around the chl a peak (Fig. 5). Because of the initial dominance of Woloszynskia halophila, diatoms were not, however, able to catch up before nutrients were depleted, despite their higher growth rates (Table 4). $\mathrm{N}+\mathrm{P}$ additions, as well as high-light levels, significantly increased diatom biomass and favored the diatoms over dinoflagellates (negative effects on dinoflagellate relative abundance). Enrichment with DSi did not produce any notable effects on diatom biomass or on the relative phytoplankton composition (Table 5). Once nutrients were exhausted, the diatom community collapsed quickly, particularly at the higher light level, whereas $W$. halophila maintained and even increased its high levels of biomass after the chl a peak, despite nutrient depletion.

The dynamics of biomass composition was reflected by the cell dynamics of the most abundant taxa (Fig. 6), with Woloszynskia halophila establishing and maintaining high abundances, and diatoms forming distinct peaks connected to the decline of nutrients. At the beginning of the experiment, cell concentrations of $W$. halophila increased rapidly in all treatments except the low-light $\mathrm{N}+\mathrm{P}$ mesocosms, where the increase was steady, but somewhat slower. The major diatom species strongly responded to the N+P additions. Abundance peaks occurred at the time of the chl a peaks, and they were shifted accordingly in the high- and low-light treatments.

Maximum abundances of Chaetoceros spp., Pauliella taeniata, Thalassiosira levanderi and T. baltica were usually observed a few days earlier in the N+P treatments, as compared to the N+P+DSi treatments (Fig. 6). Chaetoceros spp. and T. levanderi reached higher abundances in $\mathrm{N}+\mathrm{P}$ treatments without added $\mathrm{DSi}$, whereas T. baltica and Skeletonema costatum were more abundant in the N+P treatments with added DSi. After the abundance peaks, large parts of the Chaetoceros spp. and $P$. taeniata populations were transformed into spores. The proportions of spores were generally higher in the high-light treatment series (data not shown). $P$. taeniata formed most spores in the treatments without $\mathrm{N}+\mathrm{P}$ enrichment, while spores of Chaetoceros spp. were most abundant in the treatments with added $\mathrm{DSi}_{\text {, }}$ independent of initial $\mathrm{N}$ and $\mathrm{P}$ levels. 

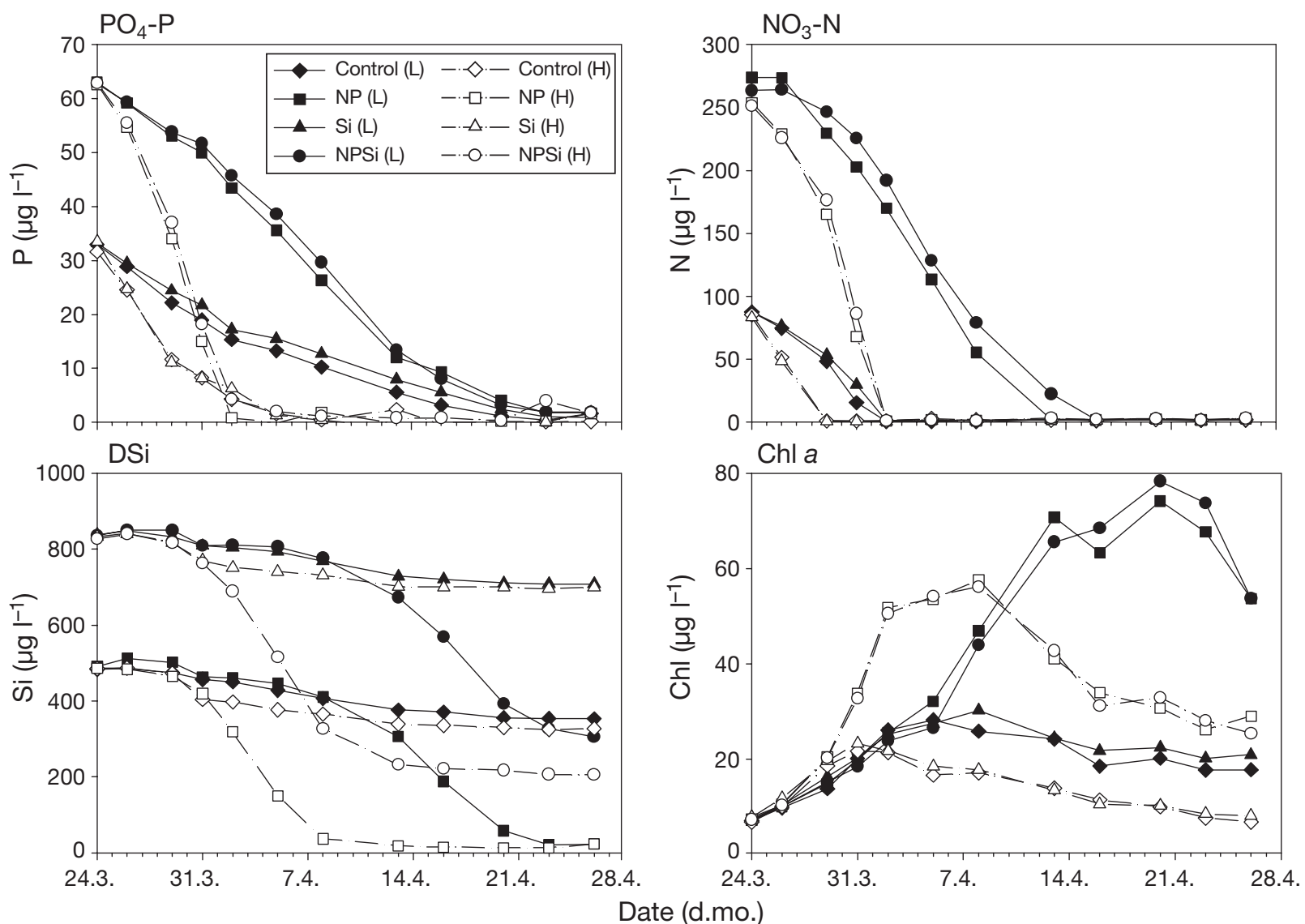

Fig. 4. Progression of inorganic nutrients $\left(\mathrm{PO}_{4}-\mathrm{P}, \mathrm{NO}_{3}-\mathrm{N}\right.$ and $\left.\mathrm{DSi}\right)$ and chl a concentrations in experimental mesocosms during spring 2004. Symbols denote experimental treatments; light levels (L, H) are as defined in Fig. 2

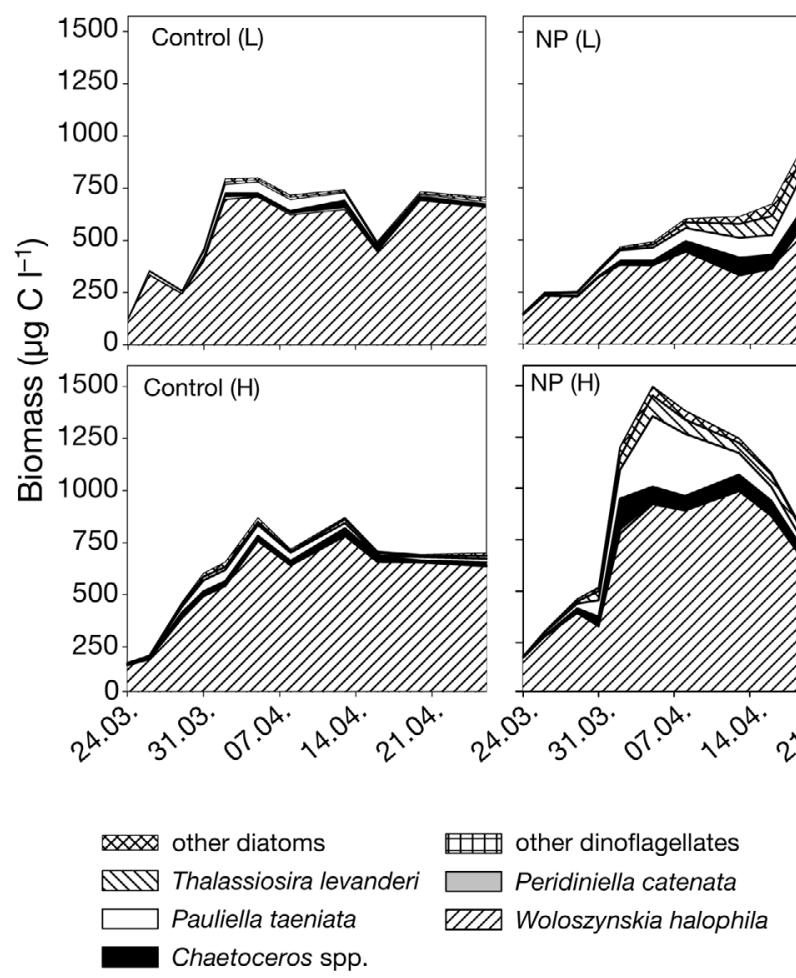

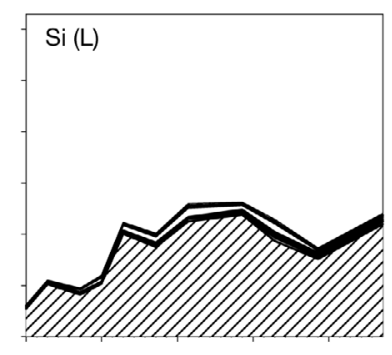
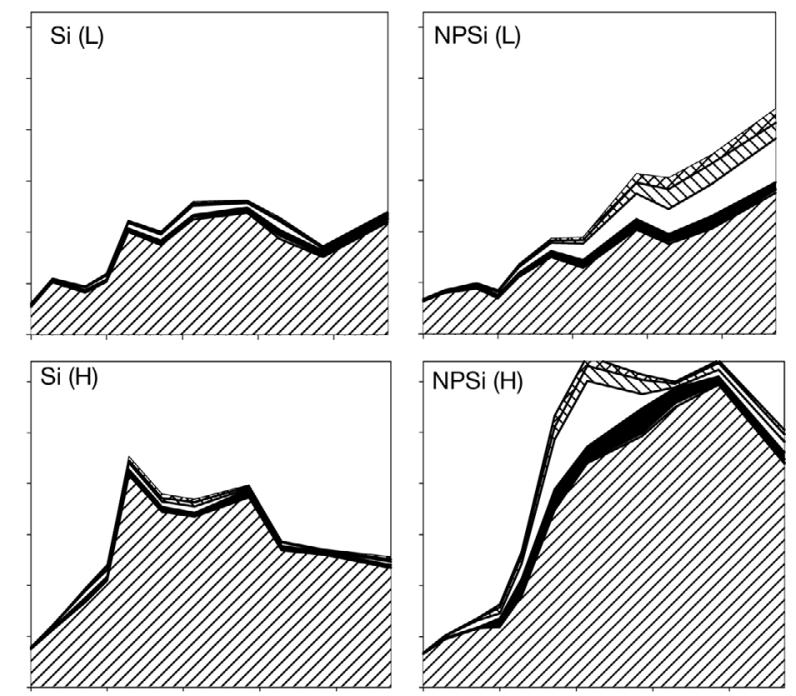

\section{Date (d.mo.)}

Fig. 5. Biomass development and relative contribution of dominant taxa to total (dinoflagellate + diatom) biomass in experimental mesocosms at low (L) and high $(\mathrm{H})$ light (levels are as defined in Fig. 2) during the 2004 experiment 


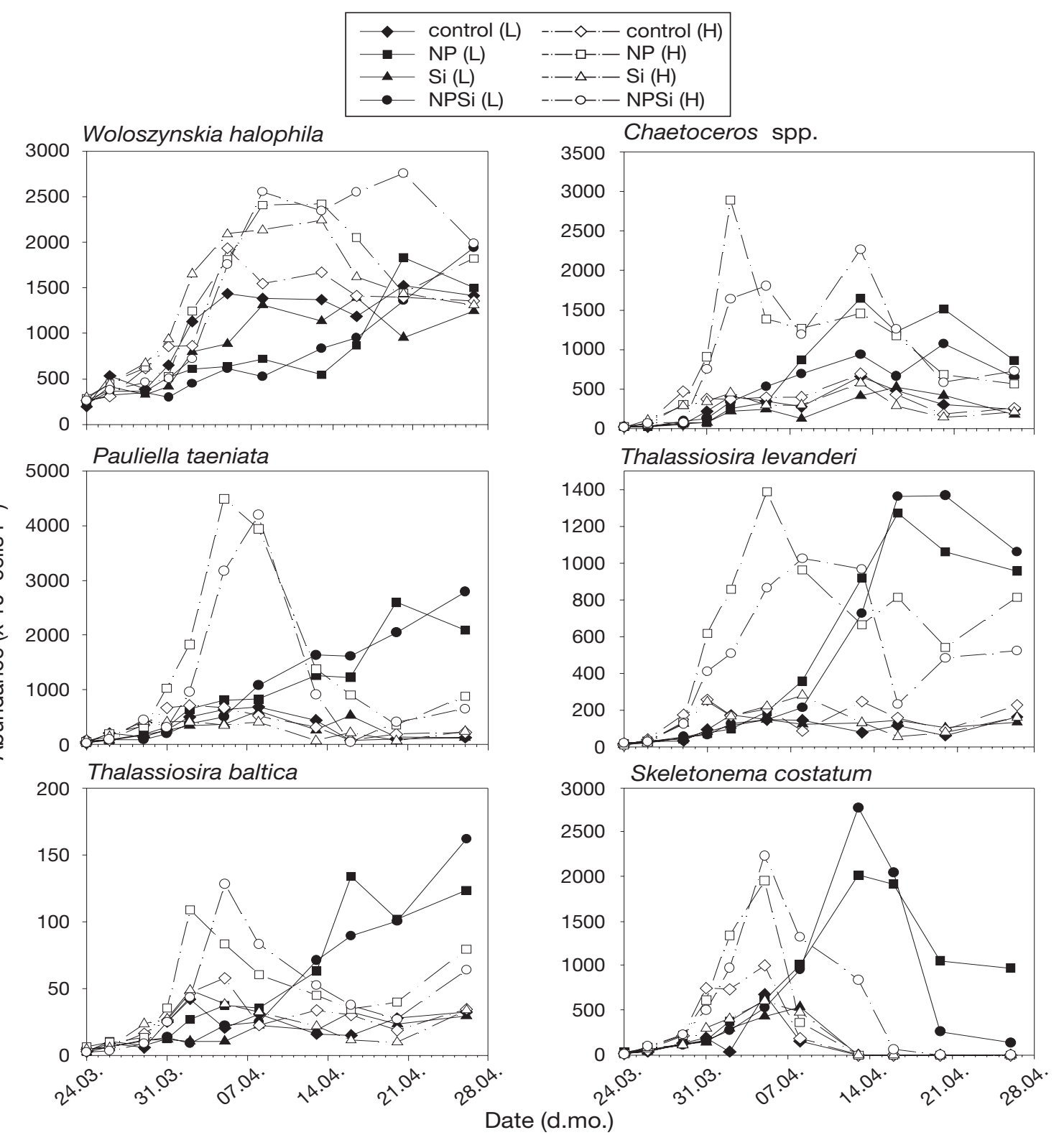

Fig. 6. Dynamics of cell abundances of dominant dinoflagellate and diatom species in experimental mesocosms during spring 2004. Light levels (L, H) are as defined in Fig. 2

\section{DISCUSSION}

The objective of this study was to examine the role of nutrient conditions and initial community composition for the development and species dominance of the phytoplankton spring bloom community in the coastal northern Baltic Sea, and specifically the competition between diatom and dinoflagellate bloom species. The mesocosm experiments revealed that dominance and bloom formation of the dinoflagellate Woloszynskia halophila depended to a large extent on the size of the inoculum's population and the relative abundance of co-occurring diatoms. Variations of initial DSi:(N+P) availability did not have a significant effect on phytoplankton community composition and dominance of either diatoms or dinoflagellates.

\section{Effects of nutrient availability on phytoplankton composition and dominance patterns}

We found that $\mathrm{N}$ and $\mathrm{P}$ additions had no (or even negative) effects on the bloom dinoflagellate Woloszynskia halophila in the multi-species communities. 
This was presumably a result of a competitive disadvantage compared to the coexisting diatoms, which generally had increased growth rates in the treatments with boosted $\mathrm{N}$ and $\mathrm{P}$ levels. Growth rates of $W$. halophila were mostly higher in the non-enriched treatments. Such a response agrees with the general conception that dinoflagellates are inferior competitors for nutrients relative to diatoms (Smayda 1997), possibly as a result of a lower maximum uptake capacity at high ambient concentrations (Lomas \& Glibert 2000). Nevertheless, in 2004, W. halophila remained the winner of the competition even in the enriched treatments, when the species was able to deplete the nutrient concentrations to limiting levels.

The increased growth rates of Woloszynskia halophila in non-enriched mesocosm treatments, and the persistence of the species during the late, nutrientdeplete stages of the experiment emphasize the high nutrient affinity of the species in low-nutrient environments. This suggests that W. halophila-though apparently a bloom species - does not represent the competitive dinoflagellate life-form type (Smayda \& Reynolds 2003) that would directly benefit from increased $\mathrm{N}$ and $\mathrm{P}$ supply and thrive in high-nutrient habitats.

The mechanisms underlying the sustained growth and persistence of the Woloszynskia halophila populations at low nutrient concentrations are not currently known. It is possible that the species, like other bloomforming dinoflagellates, possesses compensatory strategies such as mixotrophy or utilization of dissolved organic nutrients and internal nutrient storages (Legrand \& Carlsson 1998, Dyhrman \& Anderson 2003, Collos et al. 2004). Also, the role of $P$ and, accordingly, $\mathrm{N}$ :P ratios needs to be examined more thoroughly. In these experiments, we manipulated $\mathrm{N}$ and $\mathrm{P}$ concentrations in a fixed ratio, so that differences in residual nutrient concentrations between the years were due to initial ambient concentrations, and the potentially different roles of $\mathrm{N}$ and $\mathrm{P}$ cannot be systematically resolved from the data. Residual phosphate may affect the growth of dinoflagellates positively at low ambient nitrate levels (Shi et al. 2005), and due to their low optimum N:P ratios compared to diatoms, some dinoflagellate species may be selected at low ambient N:P ratios (Hodgkiss \& Ho 1997). In 2004, when dinoflagellates dominated the mesocosms, initial $\mathrm{P}$ concentrations were unusually high, and residual phosphate levels, particularly in the non-enriched treatments, were still considerable at the time of the chl a peak.

Small diatoms responded most obviously to $\mathrm{N}$ and $\mathrm{P}$ additions, which is in accordance with the general assumption that nutrient uptake is most efficient in small-sized species due to a high surface to volume ratio (Eppley et al. 1969, Malone 1980). However, spe- cies-specific responses varied between the years, presumably as a reflection of the complex competitive interactions within the differently structured communities under different initial conditions. In 2003, all major diatoms had elevated net growth rates in the enriched treatments, but growth rates were generally low, when nutrient levels at the beginning of the experiment had already been depleted to half of the winter concentrations. Most likely the highest growth rates had prevailed before the experiment, and given the high initial cell concentrations of the dominating diatoms Chaetoceros spp and Pauliella taeniata, the potential for multiplication was limited, even in the treatments with added $\mathrm{N}$ and $\mathrm{P}$.

In 2004, at comparable light conditions, only Chaetoceros spp. had higher rates of increase in the $\mathrm{N}+\mathrm{P}$ treatments. Stimulation of this species presumably imposed a competitive restriction on the other diatoms, which had generally higher growth rates in the treatments without $\mathrm{N}$ and $\mathrm{P}$ additions, where Chaetoceros spp. was not particularly favored. A similar effect was observed in 2005, when an unidentified small centric diatom with a high net growth rate contributed the major fraction of the diatom biomass in the N+P mesocosms, apparently at the expense of other small-sized species such as Chaetoceros spp. and Thalassiosira levanderi.

\section{Effects of nutrient ratios and projections to loading scenarios}

In our study, species dominance and biomass distribution of the phytoplankton community was unaffected by the variations of $\mathrm{DSi}:(\mathrm{N}+\mathrm{P})$ ratios that were applied to simulate potential changes in the nutrient regime in the surface waters of the Baltic Sea. Diatoms either prevailed or remained inferior, irrespective of initial DSi: $(\mathrm{N}+\mathrm{P})$ ratios or absolute DSi concentrations. This agrees with the findings of Kuosa et al. (1997), who showed that decreased DSi: $(\mathrm{N}+\mathrm{P})$ ratios, though affecting the composition of the spring diatom community in the northern Baltic Sea, could not limit diatom biomass development as such.

The reason for the lack of response to the DSi:N manipulations might be found in the ratios itself. An average molar DSi:N ratio of diatom biomass of 1:1 (Brzezinski 1985) is commonly considered as a threshold for DSi limitation (Levasseur \& Therriault 1987, Dortch \& Whitledge 1992). However, several studies suggest that initial DSi:N molar ratios of $<1: 2$ are necessary to induce DSi limitation and trigger a shift in species dominance towards non-siliceous phytoplankton (Sommer 1994, Schöllhorn \& Graneli 1996, Gilpin et al. 2004), which might be due to the considerable 
capability of diatoms to acclimate to DSi stress (Olsen \& Paasche 1986, Brzezinski et al. 1990). K. Spilling et al. (unpubl. data) concluded that also the major Baltic spring bloom diatoms are tolerant of low DSi concentrations, as indicated by their generally low degree of silicification and variable but low $\mathrm{K}_{\mathrm{s}}$ values.

Our nutrient manipulations, which were chosen to reflect recent and projected nutrient trends in the surface waters of the Baltic Sea (Rahm et al. 1996, Papush \& Danielsson 2006), were not able to create potentially-severe DSi limitation even at high $\mathrm{N}+\mathrm{P}$ additions to ambient DSi levels. The ambient molar DSi:N ratios of 3 successive years (ca. 2.8 to 3.8 ) were well above the 1:1 threshold ratio, and even the addition of $\mathrm{N}+\mathrm{P}$ without DSi caused the ratio to decrease just below 1:1 (0.81 to 1.09). The DSi additions, either alone or in combination with $\mathrm{N}+\mathrm{P}$ additions, basically behaved as replicates to corresponding control or $\mathrm{N}+\mathrm{P}$ additions for all parameters except for DSi (e.g. Fig. 4).

Previous studies have shown that $\mathrm{N}$ is the dominant limiting nutrient in the northern Baltic Sea, especially during the spring bloom season (Tamminen \& Andersen 2007). Our results demonstrate an excess availability of DSi relative to $\mathrm{N}$ in pre-bloom winter water in the study area, indicating that DSi should not become limiting for the diatoms at the ambient levels of $\mathrm{N}$, or even with a rather strong decrease in coastal DSi:N loading ratio. This also suggests that the reasons for the common but irregular prevalence of dinoflagellates during the spring bloom period should be sought elsewhere.

High silica availability in relation to $\mathrm{N}$ favored the formation of resting spores of Pauliella taeniata and Chaetoceros spp. in the control and DSi treatments, where initial DSi:N ratios were the highest. Diatom spores are characterized by their highly silicified walls and can only be formed at sufficient DSi supply (McQuoid \& Hobson 1996). Although spores of these 2 species were formed in all treatments, their proportion remained low in the $\mathrm{N}+\mathrm{P}$ treatment, particularly at the low irradiance level.

Pauliella taeniata, one of the most important constituents of the Baltic Sea spring diatom community, is an arctic species which is restricted to the cold season (Niemi 1973). The survival of this species through the warm season thus depends entirely on a benthic resting stage. A decreasing potential of spore formation at decreased DSi:N ratios may impair the survival of the species, which in turn could lead to a reduced seeding potential and future inoculum size. Hence, even if a decrease of DSi:N ratios in the range of realistic future scenarios would not directly cause DSi limitation and subsequent general discrimination of spring diatoms in the northern Baltic Sea, it might still affect species composition within the diatom community through effects on the survival of some important species.

\section{Effect of light on species competition}

Due to species-specific relationships between nutrient uptake and light, fluctuations of the irradiance regime are generally expected to affect nutrient competition and the structure of phytoplankton communities (Litchman et al. 2004). In our study, the stimulation of diatoms in the $\mathrm{N}+\mathrm{P}$ treatments was pronounced at the higher irradiance level. The growth of Woloszynskia halophila was also positively, but less strongly, affected by light, leading to its decreasing share within the assemblage at high light.

This could simply be an effect of the competitive interaction with the diatoms. However, it could also be a reflection of differences in light saturation. Woloszynskia halophila has a lower light saturation level than the co-occurring diatoms (Spilling \& Markager 2008). Despite the more efficient cellular growth response of the diatoms at high nutrient concentrations and higher irradiance level, a shift to diatom dominance did not occur. This is similar to the results of Sommer (1994), who found that increased irradiance affected species proportions within the diatom fraction, but did not alter the total contribution of diatoms to the phytoplankton biomass.

\section{Contrasting competition strategies of diatoms and dinoflagellates}

The responses of Woloszynskia halophila and diatoms to nutrients and light thus differed clearly from each other. Diatoms were highly significantly favored by both high-light and N+P additions, whereas the response of $W$. halophila to light was clearly weaker, and its response to $\mathrm{N}+\mathrm{P}$ additions even negative. As it is not really conceivable that nutrient abundance, at the somewhat realistic levels applied in the experiment, would inhibit growth of the dinoflagellate, this negative effect is most likely due to superior performance of diatoms at high nutrient availability. These different properties of the competing algae closely resemble the 2 contrasting selection patterns of Pianka (1970): r- and K-selection.

High growth rates and maximum nutrient uptake of diatoms describe a straightforward competition strategy based on superior fitness at low initial densities and high abundance of basic growth factors (r-selection, denoting high growth capacity), whereas Woloszynskia halophila appears to thrive, despite relatively low growth rates and low maximum uptake for nutrients, in conditions where cell densities are already high. Its capacity to maintain high densities for a prolonged period after nutrient depletion suggests high nutrient affinity at low concentrations. Cul- 
ture experiments with the dominant species in our mesocosm experiments have verified these speciesspecific growth patterns (K. Spilling et al. unpubl. data).

Woloszynskia halophila is thus favored under conditions of crowding and low resources, which is generally considered an essential feature of K-selection (denoting the carrying capacity of the environment). Complex life cycles of dinoflagellates, their larger cell sizes compared to diatoms, and the common existence within this organism group of a set of competition advantages besides high growth rate and nutrient uptake (like allelopathy and mixotrophy), all belong to traits generally associated with K-selection (Pianka 1970, Ricklefs 1979). These traits normally predominate in stable environments, whereas $\mathrm{r}$-selected traits should be progressively removed. Dinoflagellate spring blooms appear paradoxical in this respect. Within a narrow time window in a dynamically fluctuating environment, like the temperate spring bloom season, it appears essential for $W$. halophila to establish a strong head start population to be able to dominate the bloom, and the conditions which facilitate this peculiar dominance should therefore mainly relate to successful recruitment before the actual bloom season.

\section{Role and sources of initial dinoflagellate abundance for bloom formation}

Blooms of Woloszynskia halophila were only formed in the 2004 mesocosm experiment, when the species dominated the initial phytoplankton biomass and outnumbered the co-occurring diatoms by an order of magnitude. At the time of ice break-up, W. halophila had already obtained a population density of $>250 \times$ $10^{3}$ cells $1^{-1}$, equal to peak concentrations of the species in 2003. Such a large population in the inoculum provided the species a head start, which the competing diatoms could not make up for, despite their higher maximum nutrient uptake and net growth rates.

The proportionally high increase of the diatom biomass in the N+P enrichment treatments in 2004 emphasizes their high maximum growth rate in nutrient-rich waters. It is possible that a minor shift of initial proportions in favor of the diatoms could have inverted the outcome of the competition under conditions of nutrient enrichment. In an earlier study on competition of spring phytoplankton in the Baltic Sea, Woloszynskia halophila was immediately outcompeted by the co-occurring diatoms, despite equal initial biomass proportions (Kuosa et al. 1997). This is consistent with the phytoplankton development in our 2005 experi- ment, where dinoflagellates were suppressed by small fast-growing diatoms, although both groups initially contributed approximately equally to the phytoplankton biomass. Although our data do not provide clear indications for a threshold in biomass proportions that would predict the bloom winner species, it seems that a substantially superior size of the dinoflagellate seed population, relative to co-occurring diatoms, is necessary for later dominance and bloom formation of $W$. halophila.

These results emphasize that conditions which support large initial population size and initial dominance appear crucial for the development of Woloszynskia halophila blooms. It has been shown for complex diatom communities that single species recruitment strategies and conditions prevailing during the seeding stage may significantly affect later community structure and dominance distribution (McQuoid \& Godhe 2004). Efficient recruitment from the large benthic seed populations (Kremp 2000, Kremp \& Anderson 2000) together with coinciding selective hydrographical conditions obviously are important prerequisites for later dinoflagellate prevalence in the spring phytoplankton community.

Favorable hydrographical conditions most likely consist of early mixing incidents promoting seed population introduction to the water column, followed by water column stratification or population concentration by advection. Late ice cover naturally provides exceptionally stagnant low-light conditions, which have been shown to especially favor build-up of high dinoflagellate densities prior to the spring bloom season (e.g. Kremp \& Heiskanen 1999, Spilling 2007). The probability for a temporal sequence of hydrographical conditions optimal for dinoflagellate blooms obviously decreases along the coast-offshore, as well as the north-south gradients of the Baltic Sea.

Despite the near-coast origin of dinoflagellate seeding populations, they can potentially spread offshore effectively; it has been shown that the spring stratification, marking the start of the bloom season, is triggered in the brackish Baltic Sea by freshwater gradients meandering offshore from the coast, and not by temperature, as in lakes or oceans in general (Stipa 2002). The proximity to coastal seeding banks and freshwater discharges, however, is a very likely basis for the observed large-scale differences in springtime dinoflagellate abundance between northern and southern Baltic Sea areas.

Such a complexity makes the spring bloom composition highly unpredictable in the northern Baltic Sea. Due to bloom sensitivity to hydrographic conditions, long-term climatic trends potentially play a larger role in the frequency of dinoflagellate blooms than nutrient conditions at the bloom onset. 
Acknowledgements. The authors thank E. Salminen, M. Sjöblom, U. Sjölund and A. Åström for their assistance in the laboratory, and T. Sjölund for assistance on the ice. The comments and critical suggestions of 3 anonymous reviewers are gratefully acknowledged. This work was supported by the European Commission through SIBER (EVK3-CT-200200069) and SEED (GOCE-CT-2005-003875) and the Academy of Finland through grant 111336.

\section{LITERATURE CITED}

Anderson DM, Garrison DJ (1997) The ecology and oceanography of harmful algal blooms. Limnol Oceanogr 42: 1009-1035

Anderson DM, Glibert PM, Burkholder JM (2002) Harmful algal blooms and eutrophication: nutrient sources, composition, and consequences. Estuaries 25:704-726

Belgrano A, Lindahl O, Hernroth B (1999) North Atlantic Oscillation (NAO) primary productivity and toxic phytoplankton in the Gullmar Fjord, Sweden (1985-96). Proc R Soc Lond B Biol Sci 266:425-430

Berthouex PM, Brown LC 1994 Statistics for environmental engineers. Lewis Publishers, Boca Raton, FL

Box GEP, Draper NR (1978) Empirical model-building and response surfaces. Wiley, New York

Brzezinski MA (1985) The Si:C:N ratio of marine diatoms: interspecific variability and the effect of some environmental variables. J Phycol 21:347-357

Brzezinski MA, Olson RJ, Chisholm SW (1990) Silicon availability and cell cycle progression in marine diatoms. Mar Ecol Prog Ser 67:83-96

Collos Y, Gagne C, Laabir M, Vaquer A, Cecchi P, Souchu P (2004) Nitrogenous nutrition of Alexandrium catenella (Dinophyceae) in cultures and in Thau Lagoon, Southern France. J Phycol 40:96-103

Conley DJ, Schelske CL, Stoermer EF (1993) Modification of the biogeochemical cycle of silica with eutrophication. Mar Ecol Prog Ser 101:179-192

$>$ Dortch Q, Whitledge TE (1992) Does nitrogen or silicon limit phytoplankton production in the Mississippi River plume and nearby regions? Cont Shelf Res 12:1293-1309

Dyhrman ST, Anderson DM (2003) Urease activity in cultures and field populations of the dinoflagellate Alexandrium fundyense. Limnol Oceanogr 48:647-655

Edwards M, Richardson AJ (2004) Impact of climate change on marine pelagic phenology and trophic mismatch. Nature 430:881-883

Egge JK, Aksnes DL (1992) Silicate as regulating nutrient in phytoplankton competition. Mar Ecol Prog Ser 83: 281-289

Eppley RW, Rogers JN, McCarthy JJ (1969) Half saturation constants for uptake of nitrate and ammonium by marine phytoplankton. Limnol Oceanogr 14:912-920

Fogg G, Thake B (1987) Algal cultures and phytoplankton ecology, 3rd edn. University of Wisconsin Press, Madison, WI

Gilpin LC, Davidson K, Roberts E (2004) The influence of changes in nitrogen: silicon ratios on diatom growth dynamics. J Sea Res 51:21-35

Grasshoff K, Ehrhardt M, Kremling K (1983) Methods of seawater analysis. Verlag Chemie, Weinheim

Hallegraeff GM (2004) Harmful algal blooms: a global overview. In: Hallegreaff GM, Anderson DM, Cembella AD (eds) Manual on harmful marine microalgae. UNESCO, Paris, p 25-49

Harris GP (1986) Phytoplankton ecology: structure, function and fluctuation. Chapman \& Hall, London
Hecky RE, Kilham P (1988) Nutrient limitation of phytoplankton in freshwater and marine envoronments: a review of recent evidence on the effects of enrichment. Limnol Oceanogr 33:796-822

Heiskanen AS (1998) Factors governing sedimentation and pelagic nutrient cycles in the northern Baltic Sea. Monogr Boreal Environ Res 8:1-80

Heiskanen AS, Kononen K (1994) Sedimentation of vernal and late summer phytoplankton communities in the coastal Baltic Sea. Arch Hydrobiol 131:175-198

$>$ Hodgkiss IJ, Ho KC (1997) Are changes in N:P ratios in coastal waters the key to increased red-tide blooms? Hydrobiologia 352:141-147

Huisman J, Weissing FJ (2001) Fundamental unpredictability in multispecies competition. Am Nat 157:488-494

Humborg C, Smedberg E, Blomquist S, Mörth HM and others (2004) Nutrient variations in boreal and subarctic Swedish rivers: Landscape control of land-sea fluxes. Limnol Oceanogr 49:1871-1883

Jaanus A, Hajdu S, Kaitala S, Andersson A and others (2006) Distribution patterns of isomorphic cold-water dinoflagellates (Scrippsiella/Woloszynskia complex) causing 'red tides' in the Baltic Sea. Hydrobiologia 554:137-146

Kremp A (2000) Distribution, dynamics and in situ seeding potential of Scrippsiella hangoei (Dinophyceae) cyst populations from the Baltic Sea. J Plankton Res 22: 2155-2169

Kremp A, Anderson DM (2000) Factors regulating germination of resting cysts of the spring bloom dinoflagellate Scrippsiella hangoei from the northern Baltic Sea. J Plankton Res 22:1311-1327

Kremp A, Heiskanen AS (1999) Sexuality and cyst formation of the spring bloom dinoflagellate Scrippsiella hangoei in the coastal northern Baltic Sea. Mar Biol 134:771-777

Kremp A, Elbrächter M, Schweikert M, Wolny J, Gottschling M (2005) Woloszynskia halophila (Biecheler) comb. nov.: a bloom forming cold-water dinoflagellate co-occurring with Scrippsiella hangoei (Dinophyceae) in the Baltic Sea. J Phycol 41:629-642

Kuosa H, Autio R, Kuuppo P, Setälä O, Tanskanen S (1997) Nitrogen, silicon and zooplankton controlling the Baltic spring bloom: an experimental study. Estuar Coast Shelf Sci 45:813-821

Legrand C, Carlsson P (1998) Uptake of high molecular weight dextran by the dinoflagellate Alexandrium catenella. Aquat Microb Ecol 16:81-86

Levasseur ME, Therriault JC (1987) Phytoplankton biomass and nutrient dynamics in a tidally induced upwelling: the role of the $\mathrm{NO}_{3}: \mathrm{SiO}_{4}$ ratio. Mar Ecol Prog Ser 39:87-97

Litchman E, Klausmeier CA, Bossard P (2004) Phytoplankton nutrient competition under dynamic light regimes. Limnol Oceanogr 49:1457-1462

Lomas MW, Glibert PM (2000) Comparisons of nitrate uptake, storage, and reduction in marine diatoms and flagellates. J Phycol 36:903-913

Margalef R (1978) Life-forms of phytoplankton as survival alternatives in an unstable environment. Oceanol Acta 1:493-509

Martin-Jézéquel V, Hildebrand M, Brzezinski MA (2000) Silicon metabolism in diatoms: implications for growth. J Phycol 36:821-840

McQuoid M, Godhe A (2004) Recruitment of coastal planktonic diatoms from benthic versus pelagic cells: variation in bloom development and species composition. Limnol Oceanogr 49:1123-1133

McQuoid M, Hobson L (1996) Diatom resting stages. J Phycol 32:889-902 
Menden-Deuer S, Lessard EJ (2000) Carbon to volume relationships for dinoflagellates, diatoms, and other protist plankton. Limnol Oceanogr 45:569-579

Niemi Å (1973) Ecology of phytoplankton in the Tvärminne area, SW coast of Finland. I. Dynamics of hydrography, nutrients, chlorophyll $a$ and phytoplankton. Acta Bot Fenn 100:1-68

Niemi $\AA$ (1975) Ecology of phytoplankton in the Tvärminne area, SW coast of Finland. II. Primary production and environmental conditions in the archipelago and the sea zone. Acta Bot Fenn 105:1-73

Officer CB, Ryther JH (1980) The possible importance of silicon in marine eutrophication. Mar Ecol Prog Ser 3:83-91

Olsen S, Paasche E (1986) Variable kinetics of silicon-limited growth in Thalassiosira pseudonana (Bacillariophyceae) in response to changed chemical composition of the growth medium. Br Phycol J 21:183-190

Papush L, Danielsson Å (2006) Silicon in the marine environment: dissolved silica trends in the Baltic Sea. Estuar Coast Shelf Sci 67:53-66

Pianka ER (1970) On r- and K-selection. Am Nat 104:592-597

Rahm L, Conley D, Sandén P, Wulff F, Stålnacke P (1996) Time series analysis of nutrient inputs to the Baltic Sea and changing DSi:DIN ratios. Mar Ecol Prog Ser 130:221-228

Ricklefs RE (1979) Ecology. Thomas Nelson \& Sons, Sunburyon-Thames

Schöllhorn E, Graneli E (1996) Influence of different nitrogen to silica ratios and artificial mixing on the structure of a summer phytoplankton community from the Swedish west coast (Gullmarfjord). J Sea Res 35:159-167

Shi Y, Hu H, Cong W (2005) Positive effects of continuous low nitrate levels on growth and photosynthesis of Alexandrium tamarense (Gonyaulacales, Dinophyceae). Phycol Res 53:43-48

Smayda TJ (1990) Novel and nuisance phytoplankton blooms in the sea: evidence for a global epidemic. In: Graneli E, Edler L, Anderson DM (eds) Toxic marine phytoplankton. Elsevier, Amsterdam, p 29-39

Smayda TJ (1997) Harmful algal blooms: their ecophysiology and general relevance to phytoplankton blooms in the sea. Limnol Oceanogr 42:1137-1153

Editorial responsibility: Hugh MacIntyre, Dauphin Island, Alabama, USA
Smayda TJ, Reynolds CS (2001) Community assembly in marine phytoplankton: application of recent models to harmful dinoflagellate blooms. J Plankton Res 23: $447-461$

Smayda TJ, Reynolds CS (2003) Strategies of marine dinoflagellate survival and some rules of assembly. J Sea Res 49:95-106

Sommer U (1994) The impact of light intensity and daylength on silicate and nitrate competition among marine phytoplankton. Limnol Oceanogr 39:1680-1688

Sommer U (1998) From algal competition to animal production: enhanced ecological efficiency of Brachionus plicatilis with a mixed diet. Limnol Oceanogr 43: 1393-1396

Spilling K (2007) Dense sub-ice bloom of dinoflagellates in the Baltic Sea, potentially limited by high $\mathrm{pH}$. J Plankton Res 29:895-901

Spilling K, Markager S (2008) Ecophysiological growth characteristics and modeling of the onset of the spring bloom in the Baltic Sea. J Mar Syst (in press)

Stipa T (2002) Temperature as a passive isopycnal tracer in salty, spiceless oceans. Geophys Res Lett 29:1953, doi:10.1029/2001GL014532

Sun J, Liu D (2003) Geometric models for calculating cell biovolume and surface area for phytoplankton. J Plankton Res 25:1331-1346

Tamminen T (1995) Nitrate and ammonium depletion rates and preferences during a Baltic spring bloom. Mar Ecol Prog Ser 120:123-133

Tamminen T, Andersen T (2007) Seasonal phytoplankton nutrient limitation patterns as revealed by bioassays over Baltic Sea gradients of salinity and eutrophication. Mar Ecol Prog Ser 340:121-138

Tilman D (1982) Resource competition and community structure. University Press, Princeton, NJ

$>$ Wasmund N, Uhlig S (2003) Phytoplankton trends in the Baltic Sea. ICES J Mar Sci 60:177-186

$>$ Wasmund N, Nausch G, Matthäus W (1998) Phytoplankton spring blooms in the southern Baltic Sea: spatio-temporal development and long term trends. J Plankton Res 20: 1099-1117

Submitted: February 16, 2007; Accepted: October 31, 2007 Proofs received from author(s): January 16, 2008 